\title{
Linear-Patterned Slopes in the Discontinuous Permafrost Zone of the Central Mackenzie River Valley
}

\author{
C. B. CRAMPTON ${ }^{1}$
}

\begin{abstract}
In the Mackenzie River Valley between Norman Wells and Fort Simpson a study of the character, distribution and orientation of gently-inclined, linear-patterned slopes revealed that most northeast-facing, lichen-covered slopes have permafrost within about 10-25 inches of the surface, and display evidence that cryoturbation was once operative in the active layer. Most lineated slopes without near-surface permafrost face southwest, are surficially more moist, and are characteristically associated with sedges and Sphagnum. On these slopes that receive the greatest incoming solar radiation, and where the active layer is thicker, there is little evidence that cryoturbation was once operative. The northeast-facing slopes generally provide forage for caribou; the southwest-facing slopes are least subject to gully erosion.
\end{abstract}

RÉSUMÉ. Pentes à dessin linéaire dans la zone de permagel discontinu, dans le centre de la vallée du Mackenzie. Une étude sur la nature, la distribution et l'orientation de pentes légères à dessin linéaire dans la vallée du Mackenzie, entre Norman Wells et Fort Simpson, révèle que la plupart des pentes qui font face au Nord-Est et sont couvertes de lichens sont pergelées à moins de $25-65 \mathrm{~cm}$. de la surface et montrent des signes de cryoturbation ancienne du mollisol.

La plupart des pentes à dessin linéaire où le permagel n'est pas près de la surface font face au Sud-Ouest, sont plus humides en surface et sont typiquement associées aux laîches et aux Sphagnum. Sur ces pentes qui reçoivent le plus grand rayonnement solaire incident et où le mollisol est plus épais, il y a peu d'indices d'une cryoturbation ancienne.

Les pentes qui font face au Nord-Est donnent généralement du fourrage à caribou; celles qui font face au Sud-Ouest sont les moins sujettes au ravinement.

РЕЗЮМЕ. Склоны с линейной структурой в зоне прерывистой вечной мерзлоты чентральной долины Макензи. Иаучение характера, распределения и ориентации покатых склонов с линейной структурой показывает, что на большинстве обращенных на северо-восток и погрытых пипайником склонов вечная мервлота проникает на влубину от 25 до.60 см, шри әтом в них очевидны следы гриотурбации, когда-то имевшей место в деятельном слое. Болышинство линейных склонов без приповерхностной вечной мерзлоты обращено на юго-запад, причем эти склоны имеют более высокую влажность поверхности и характеризуются произрастанием на них осоки и сфагнума. На этих склонах, получающих наибольшее количество солнечной радиации и обладающих более глубоким деятельным слоем, мало что свидетельствует о прежней криотурбации. Обращенные на северо-запад склоны производят в основном корм для карибу; обрапенные на юго-запад склоны менее всего подвержены овражной эрозии.

\section{INTRODUCTION}

The study area lies within the central Mackenzie River valley between Norman Wells and Fort Simpson (Fig. 1). Lower Palaeozoic limestones, dolomites, sand-

${ }^{1}$ Department of Geography, Simon Fraser University, Burnaby, B.C., Canada. 


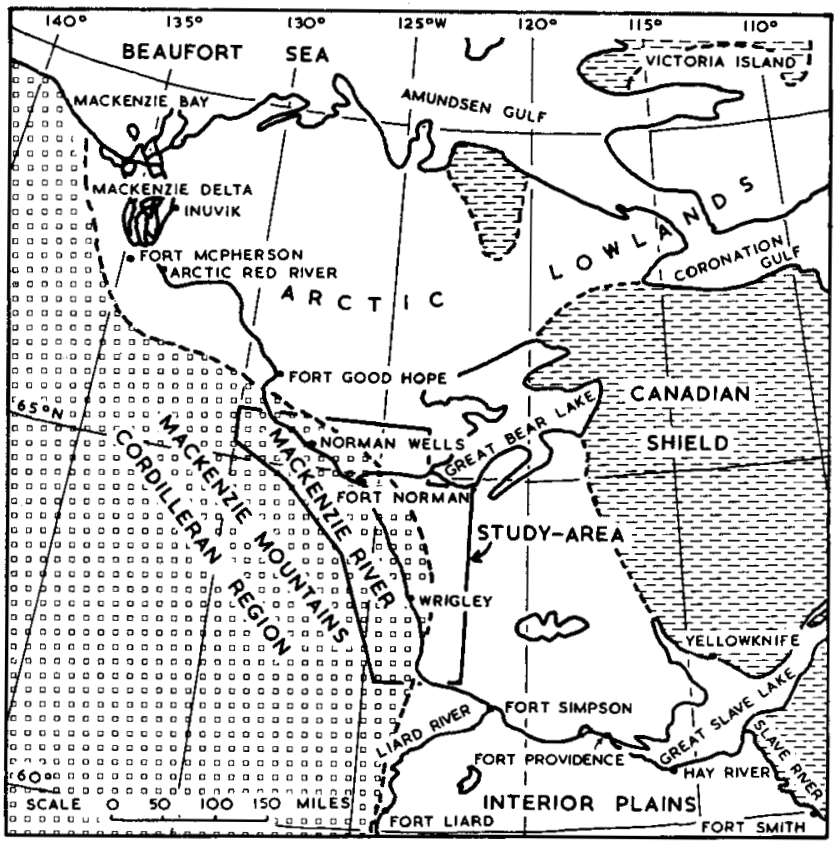

FIG. 1. Location of the study area, showing physiographic regions (Brown 1967) and some aspects of the topography.

stones and shales which mostly form the Mackenzie Mountains (part of the Cordilleran Region) west of the Mackenzie River, have been thrust eastwards to form the mountainous Norman and McConnell Ranges east of the River (Douglas 1968). In this eastern part of the study area, outliers of Upper Mesozoic shales and limestones form plateau lands such as the Ebutt Hills in the southeast, or lowlands as in the northeast. Gently inclined lands are extensive on the footslopes of the mountain ranges, and/or the slopes fringing plateaus. The area was glaciated by the Wisconsin ice-sheet off the Canadian Shield to the east, which abutted against, and over-rode the crest of the Mackenzie Mountains. Glaciers in their retreat left widespread morainal and lacustrine deposits (Craig 1965), especially on the long, gentle slopes.

The study area lies within the discontinuous permafrost zone (Brown 1967) and has a dry climate which is characterized by an annual precipitation of about 15 inches $(38 \mathrm{~cm}$.), except over high ground where it is greater. Shallow runnels oriented downslope drain the gently-sloping lands during the spring thaw. It was the objective in this study to determine the relationships of permafrost to aspect on these slopes.

\section{PROCEDURE}

During the summers of 1971 and 1972, landscape (landform and vegetation) patterns identifiable from the air, and having significance in terms of the presence or absence of near-surface permafrost conditions, were surveyed and mapped (Crampton 1973) from helicopters to identify appropriate localities for ground observations. The frequency of ground checks was related directly to the nature of the terrain and the observers' familiarity with the terrain. On many long, gentle 
slopes (i.e. inclined at about $\left.3^{\circ}\right)$ the surficial organic layer, $2-4 \mathrm{ft}$. $(61-122 \mathrm{~cm}$.) thick, is marked by a sub-parallel drainage pattern of shallow runnels oriented downslope. The smallest runnels are about 50 yards $(46 \mathrm{~m}$.) apart, and the largest about 600 yards $(549 \mathrm{~m}$.) apart. The vegetation varies with the proximity of permafrost to the ground surface. The relationship of permafrost to aspect in these linear-patterned slopes was studied by comparing their mapped distributions.

\section{RESULTS}

\section{Slopes with a thin active layer}

The permafrost table (which can be reached during most late summers) is located near the surface, and so there is a shallow active layer on gentle slopes. The organic layer is generally $18-24$ inches $(46-61 \mathrm{~cm}$.) thick. The lineation of this terrain is characterized by parallel ridges and runnels in the peaty surface. On the ridges, lichen (mostly Cladonia alpestris (L.) Rabenth.) grows profusely, giving a high albedo, which must influence the thickness of the active layer. After winter freezing the spring discharge of meltwater takes place almost entirely over the surface, within the runnels.

Lichen is characteristically dry in summer, especially in this region of low rainfall. If the lichen is associated with a thin surface layer of dry peat, a low thermal conductivity further inhibits warming of the underlying substrate (Brown and Johnston 1964). On northeast-facing slopes, snow accumulates in the drainage runnels and is preserved for longer during snow-melt, but the ridges are generally blown clear of snow during winter, which probably aids the continuance of lichen growth. The lichen is to be found with labrador tea (Ledum palustre L.), dwarf birch (Betula glandulosa Michx.), bog cranberry (Vaccinium vitis-idaea L.) and shrubby cinquefoil (Potentilla fruticosa L.). Club-topped, stunted black spruce (Picea mariana (Mill.) BSP), rarely exceeding $15 \mathrm{ft}$. (4.6 m.) in height is to be found scattered across the slopes, often slightly concentrated in the more moist runnels where the permafrost table lies at a greater depth below the ground surface, and where there is a carpet of Sphagnum spp.

Once ignited, a lichen-ericaceous-dwarf birch vegetation burns fiercely. By completely or partially removing the vegetative cover, intense fires lead to an increase in the thickness of the active layer, and greatly alter the appearance of the landscape.

On these slopes with near-surface permafrost, in the runnels the soils are "cryic peaty regosols", with the permafrost table as deep as 50 inches $(127 \mathrm{~cm}$.) below the ground surface. On the ridges the permafrost is generally at a much smaller depth, though it displays a certain irregularity. The surface is mounded, each mound being defined by cracks approximately polygonal in formation. Frozen ground occurs within about 10 inches $(25 \mathrm{~cm}$.) of the surface below the cracks, but the permafrost table is inclined gently downwards underneath the mound, dropping to about 25 inches $(64 \mathrm{~cm}$.) under its centre. Locally, some of the organic matter has been taken down and mixed with the mineral soil, suggestive of cryoturbation, and the soils may be called "turbic peaty regosols". Trees that have chanced to grow near the cracks eventually lean, to produce the "drunken forest" 


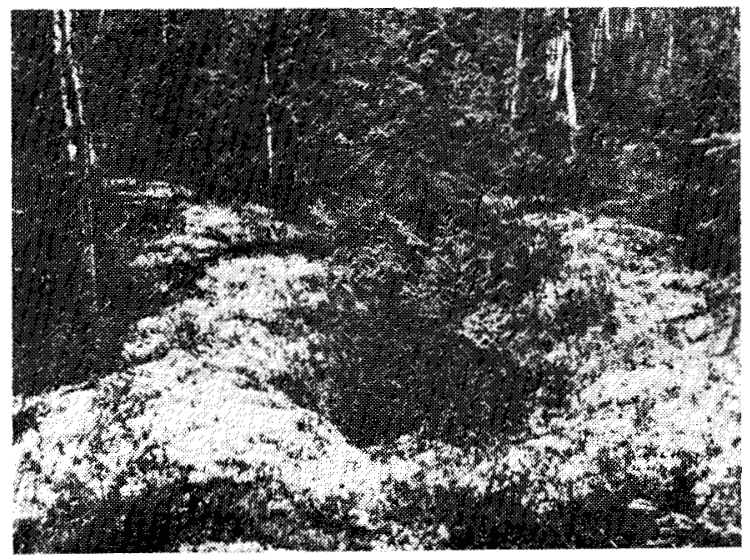

FIG. 2. Upper: black spruce-lichen forest on gentle slope, with mounds tending to merge, align and help form the minor ridges oriented downslope. Lower: example of erosional gully on lineated slope after fire.

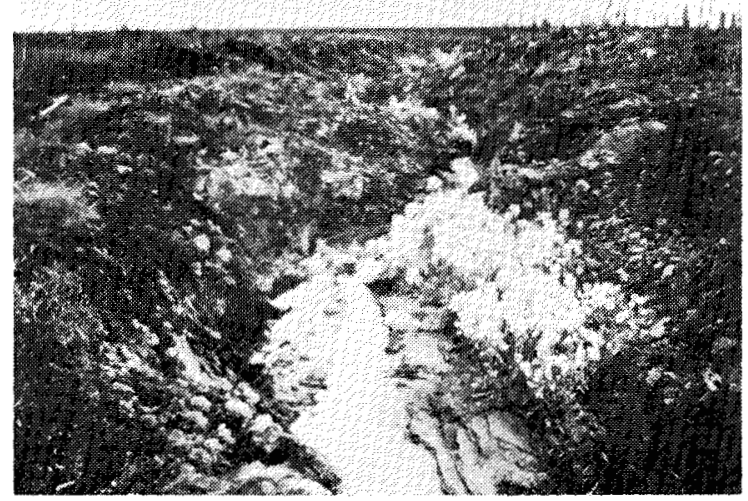

effect. The mounds tend to join, to be aligned parallel to, and help form, the minor ridges elongated downslope (Fig. 2).

At high altitudes in alpine tundra, or at high latitudes in arctic tundra, apparently-cryoturbated material disrupts the surface vegetative and organic layers, spilling through a central mound orifice onto the ground surface, suggestive of still-active cryoturbation. On slopes with near-surface permafrost within the study area, the vegetative mat is unbroken, implying that any cryoturbation structures inside the mounds are partly fossil structures, indicative of colder conditions in the past.

\section{Slopes with a thick active layer}

Where the permafrost table occurs much further below the surface of gently sloping land, as deep as $5 \mathrm{ft}$. $(152 \mathrm{~cm}$.) the soil profile layering is normal and horizontal. Sphagnum species such as Sphagnum fuscum (Schimp.) H. Klingr. and Sphagnum rubellum Wils, occur in the parallel runnels and, locally, on the low ridges between runnels, indicative of moist conditions at the surface. Lichen is much less widespread, and sedges such as tufted bog-cottongrass (Eriophorum spissum Farm.) are common. Hence, in air photographs the land appears darker. 
The dwarf birch and shrubby cinquefoil shrub layer is higher and more thickly developed than where the permafrost table occurs near the surface. Where the active layer is thick, tamarack (Larix laricina (Du Roi) K. Koch) and white birch (Betula papyrifera Marsh.) trees are to be found with the black spruce. The spruce may be up to $30 \mathrm{ft}$. $(9.1 \mathrm{~m}$.) high, especially on drier parts where it is often white spruce (Picea glauca (Moench) Voss). The soils are generally "peaty rego gleysols", though where conditions are less wet, and some seasonal downward movement of water produces some translocation of clay, there may be Gleyed Eutric Brunisols or Brunisolic Luvisols.

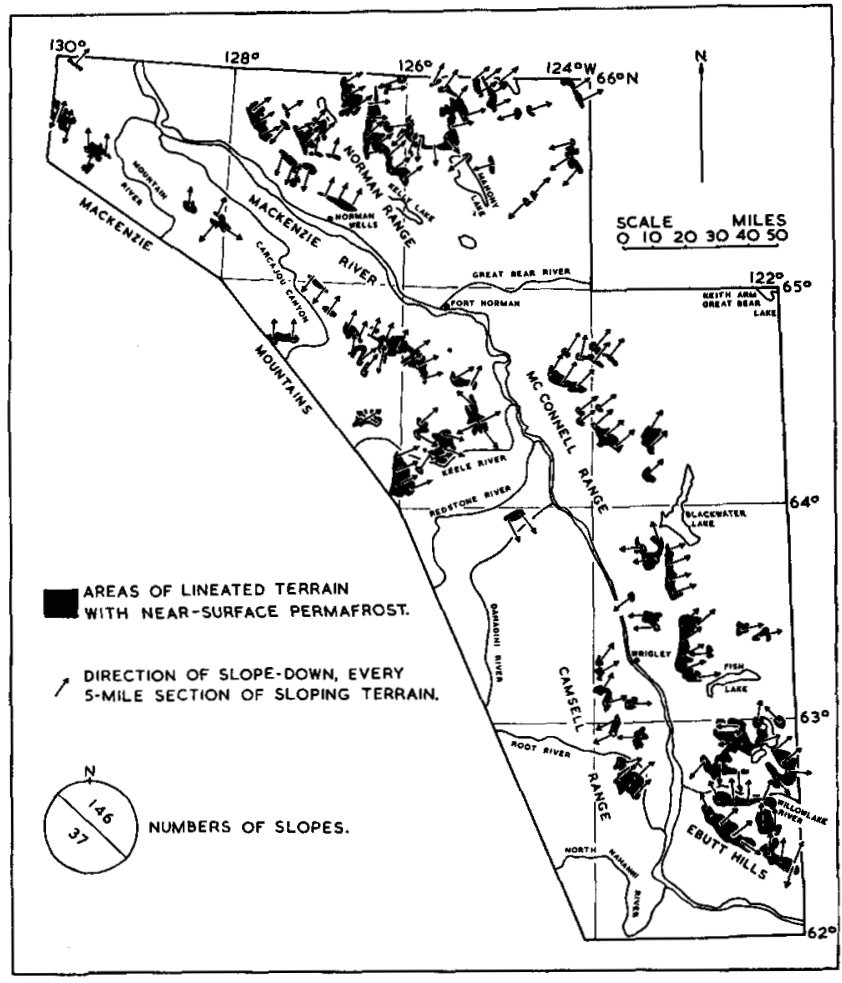

FIG. 3. Distribution and geographical orientation of lineated slopes with near-surface permafrost.

\section{INTERPRETATION OF SLOPE ORIENTATION}

If the distribution and slope orientation of lineated terrain with near-surface permafrost is plotted (Fig. 3), it is apparent that there is a pronounced concentration of such slopes facing northeast, the aspect that is warmed least during the summer. Though now inactive, cryoturbation features in the active layer of slopes with this orientation suggest they have been the cooler slopes in the past. A similar plotting of lineated terrain without near-surface permafrost (Fig. 4) shows a pronounced concentration of slopes facing southwest, the aspect that receives greatest warmth when the sun is moving to the southwest during early afternoon (Geiger 1950). By refuting the null hypothesis, a chi-square test (Table 1) suggests that there is a highly significant relationship (at greater than the 0.005 level) between the two types of lineated terrain, with and without near-surface perma- 
frost, and aspect. This is illustrated for one domed, macrorelief structure (Fig. 5).

A comparison of Figs. 3 and 4 shows that the long, gently inclined, southwestfacing slopes of highlands such as the Ebutt Hills, the McConnell Range east of the Mackenzie River and the Mackenzie Mountains west of the river, are associated mostly with a thicker active layer than are the opposite slopes. Northeast-facing slopes with near-surface permafrost are particularly widespread in the Norman Range, which area is separated distinctly from a lowland area to the southeast where there are many lineated slopes facing southwest and having a (relatively) deep-seated permafrost table.

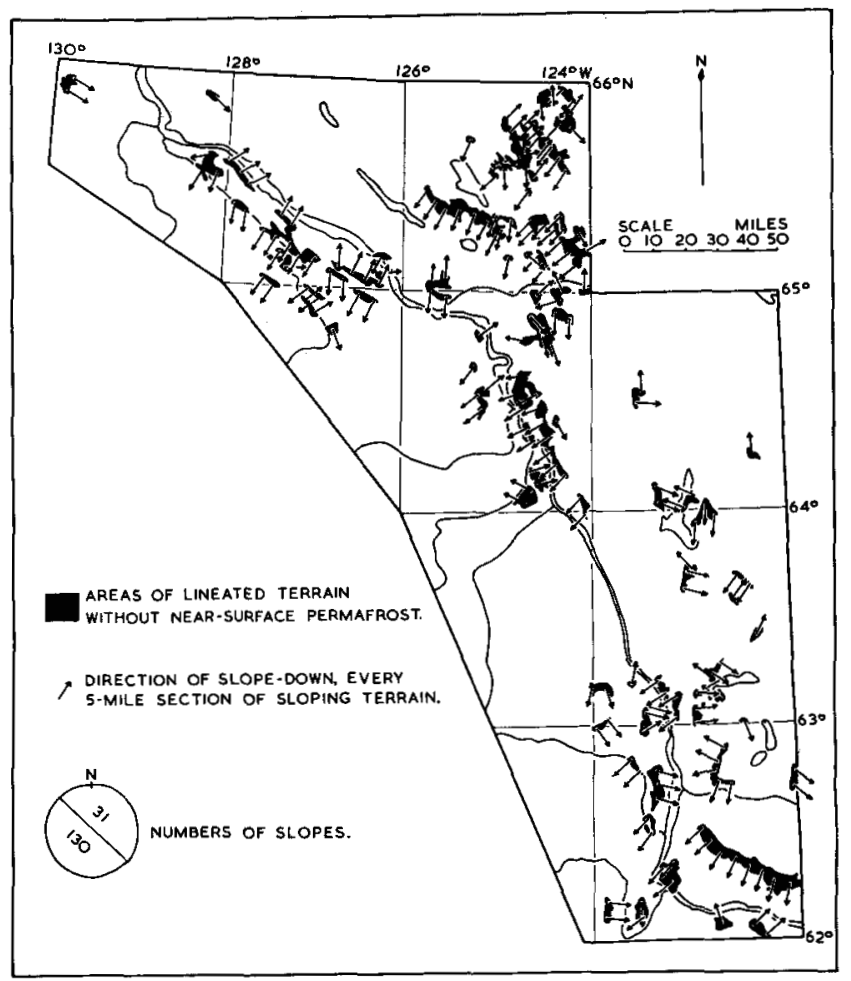

FIG. 4. Distribution and geographical orientation of lineated slopes without near-surface permafrost.

TABLE 1. Chi-square test for type of terrain (with or without permafrost near the land surface) and aspect (generalized slopes facing NE or SW).

\begin{tabular}{|c|c|c|c|c|c|}
\hline \multirow{2}{*}{ Terrain-type } & \multirow{2}{*}{ Aspect } & \multirow{2}{*}{$\begin{array}{l}\text { Observed } \\
\text { frequency } \\
\quad(0)\end{array}$} & \multirow{2}{*}{$\begin{array}{l}\text { Hypothetical } \\
\text { frequency } \\
(\mathrm{H})\end{array}$} & \multirow{2}{*}{$0-\mathrm{H}$} & $(0-H)^{2}$ \\
\hline & & & & & $\mathbf{H}$ \\
\hline \multirow{2}{*}{$\begin{array}{l}\text { Lineated terrain } \\
\text { with near-surface } \\
\text { permafrost }\end{array}$} & $\mathrm{NE}$ & 146 & 94.158 & +51.842 & 28.543 \\
\hline & SW & 37 & 88.850 & -51.850 & 30.258 \\
\hline \multirow{3}{*}{$\begin{array}{l}\text { Lineated terrain } \\
\text { without near-surface } \\
\text { permafrost }\end{array}$} & NE & 31 & 82.830 & -51.830 & 32.432 \\
\hline & SW & 130 & 78.162 & +51.838 & 34.380 \\
\hline & TOTALS & 344 & 344.000 & 00.000 & $125.613^{*}$ \\
\hline
\end{tabular}

*Chi-squared total which, for 1 degree of freedom, is significant at $>0.005$ level 


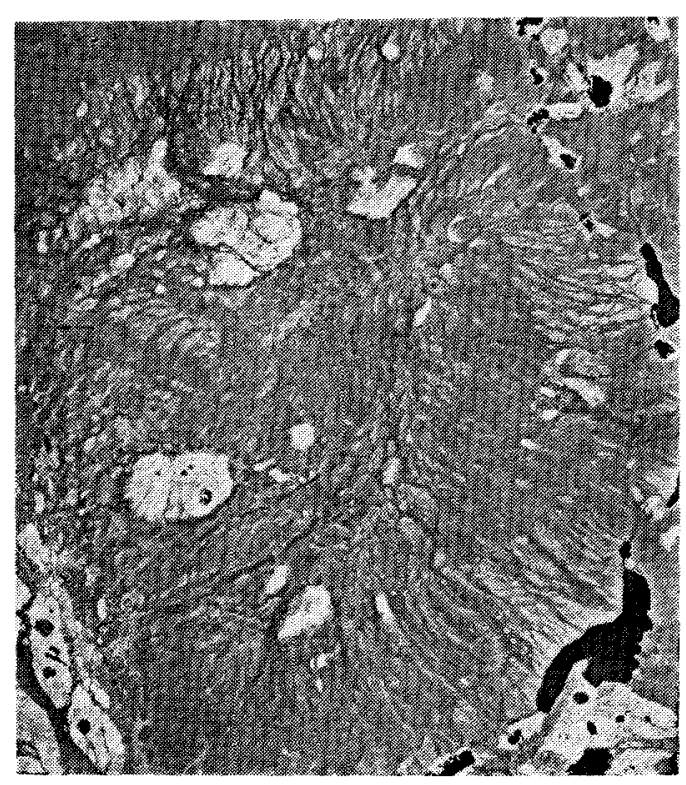

FIG. 5 Domed macrorelief structure showing the variation of type of linear-patterned slope with aspect, the pattern associated with near-surface permafrost occurring mostly on NNWto SE-facing slopes, and the pattern not associated with near-surface permafrost occurring mostly on SSEto W-facing slopes (part of air photograph A12599-248, Air Photo Division, Dept. of Energy, Mines and Resources, Canadian Government copyright, scale $1: 63360$, with north towards top of page).

Because the permafrost table is near the ground surface on many of the seasonally dry, gentle slopes facing northeast, stripping the vegetative cover and, especially, the organic layer (Strang 1973) by natural fires or by indifferently handled machinery exposes and melts the frozen substrate in summer. The melted subsoil is charged with water to form a slurry, which readily moves downslope, exposing more frozen substrate. In this way the process of erosion continues, and deep gullies are often formed (Fig. 2). Gullying is much less likely to occur on southwest-facing slopes because there the permafrost is deeper and less easily exposed.

Wildfires affect caribou considerably as it takes a very long time for the vegetation in burnt areas to again become capable of supporting these animals. This winter range of the caribou consists primarily of open, mature black sprucelichen forest, mostly the better drained, gently sloping or slightly rolling areas. The most extensive black spruce-lichen forest of this character occurs on lineated slopes facing northeast, land where the active layer is never deeply developed, and which is associated with a thick lichen mat for forage. This fact is consistent with the report (Watson et al. 1973) that the caribou range associated with, for example, the McConnell Range of mountains extends from east of the Range during early winter, to the base of the eastern slopes of the Range during late winter, and possibly onto the Range during summer. In general, caribou ranges do not extend to the south of mountain chains.

\section{CONCLUSIONS}

The distribution and orientation of linear-patterned, gently sloping lands in the central Mackenzie River valley shows a predominance of northeast-facing slopes with a permafrost table near the surface, and a rich lichen flora. The thick- 
ness of the active layer varies from point to point within a complex, local mounding of the surface topography, probably having been produced by now inactive cryoturbation during seasonal freezing of the active layer. Northeast-facing slopes receive the least incoming solar radiation, compared with the opposite slopes. Most southwest-facing slopes have a thicker active layer, a vegetation characterized by sedges instead of lichen, a greater spread of Sphagnum and larger trees, and their substrate is little disturbed by cryoturbation.

Because the permafrost is at a greater depth below the ground surface, southwest-facing slopes are least affected by fire or by disturbance of the surficial vegetative and organic layers. In contrast, fire or disturbance can produce gullying on the seasonally drier, northeast-facing slopes. The rich lichen vegetation on northeast-facing slopes generally provides good forage for the caribou which seasonally migrate from the east across them onto their summer mountain habitat.

\section{ACKNOWLEDGEMENT}

The mapping was undertaken during investigations carried out under the Environmental-Social Program, Northern Pipelines, of the Task Force on Northern Oil Development of the Government of Canada.

\section{REFERENCES}

BRown, R. J. E. 1967. Permafrost in Canada. Canada, National Research Council, Division of Building Research.

BROWN, R. J. E. and G. H. JOHNSTON. 1964. Permafrost and related engineering problems. Endeavour, 23: 66-72.

CRAIG, B. G. 1965. Glacial Lake McConnell and the surficial geology of parts of Slave River and Redstone River map areas, District of Mackenzie. Canada, Geological Survey, Bulletin no. 122.

CRAMPTON, C. B. 1973. Studies of vegetation, landform and permafrost in the Mackenzie Valley: landscape survey in the upper and central Mackenzie Valley. Canada, Department of the Environment, Forestry Service, Northern Forest Research Centre, Report no. 73-8, Information Canada Catalogue no. R72-8073. (Contribution to the Environmental-Social Program, Northern Pipelines, of the Task Force on Northern Oil Development.)

Douglas, R. J. W. (compiler). 1968. Geological Map of Canada. Ottawa: Department of Energy, Mines and Resources (Geological Survey).

GEIGER, R. 1950. Climate near the Ground. Cambridge: Harvard University Press.

STRANG, R. M. 1973. Studies of vegetation, landform and permafrost in the Mackenzie Valley: some case histories of disturbance. Canada, Department of the Environment, Forestry Service, Northern Forest Research Centre, Report no. 73-14, Information Canada Catalogue no. R72-8173. (Contribution to the Environmental-Social Program, Northern Pipelines, of the Task Force on Northern Oil Development.)

WATSON, G. H., et al. 1973. An inventory of wildlife habitat of the Mackenzie Valley and the Northern Yukon. Canada, Department of the Environment, Wildlife Service, Special Habitat Evaluation Group, Report no. 73-27, Information Canada Catalogue no. R72-12273. (Contribution to the Environmental-Social Program, Northern Pipelines, of the Task Force on Northern Oil Development.) 